\title{
Fish Diversity of Tamor River and Its Major Tributaries of Eastern Himalayan Region of Nepal
}

\author{
Jiwan Shrestha, Dharani Man Singh and Tej Bahadur Saund \\ Fish Hotspot Group, Kathmandu \\ e-mail:saudtej@gmail.com
}

\begin{abstract}
A total of 30 fish species from different sampling stations were recorded. Psilorhynchoides pseudecheneis, endemic fish of Nepal, was recorded from all seven stations, which can be considered as a common species of the study area. Recorded fish species were classified into two orders and five families. Order Cypriniformes comprised of four families: Cyprinidae, Cobitidae, Balitoridae and Psilorhynchidae with 26 species while order Siluriformes comprised of one family: Sisoridae and four species. Cyprinidae, Cobitidae, Balitoridae and Psilorhynchidae comprised $61 \%, 13 \%, 10 \%$ and 3\% respectively while Sisoridae comprised of $13 \%$ fish species. The common species of Tamor river were Psilorhynchoides pseudecheneis followed by Barilius shacra, Barilius bendelisis, Barilius barila, Schizothoraichthys labiatus, Schizothoraichthys progastus, Schizothorax richardsonii, Neolissochilus hexagonolepis and Garra annandalei. Most of the species collected during the field survey have economic value as food, medicinal, recreation and aesthetic purposes. The water quality parameters i.e. air temperature $\left(22-26.3^{\circ} \mathrm{C}\right)$, water temperature $\left(16.0-19.0^{\circ} \mathrm{C}\right)$, DO (9.7-10 ppm), pH (7.3-7.5), alkalinity (17.1 mg/l), total hardness (28.5-34.2 mg/l), $\mathrm{CO}_{2}(5 \mathrm{mg} / \mathrm{l})$ and conductivity (37.7$56.7 \mu \mathrm{s} / \mathrm{cm}$ ) were found within the suitable range for cold water fishes.
\end{abstract}

Key words: Eastern Himalayas region, Tamor river, fish diversity, fish dominancy, physico-chemical parameters

\section{Introduction}

The Eastern Himalayas Region (EHR) comprises Bhutan, Northeastern India including Darjeling district in West Bengal, and Southern, central and eastern Nepal (Fig. 1) including Koshi river basin. Saptakoshi is the largest river basin in Nepal with its huge catchment area $\left(256000 \mathrm{~km}^{2}\right)$.

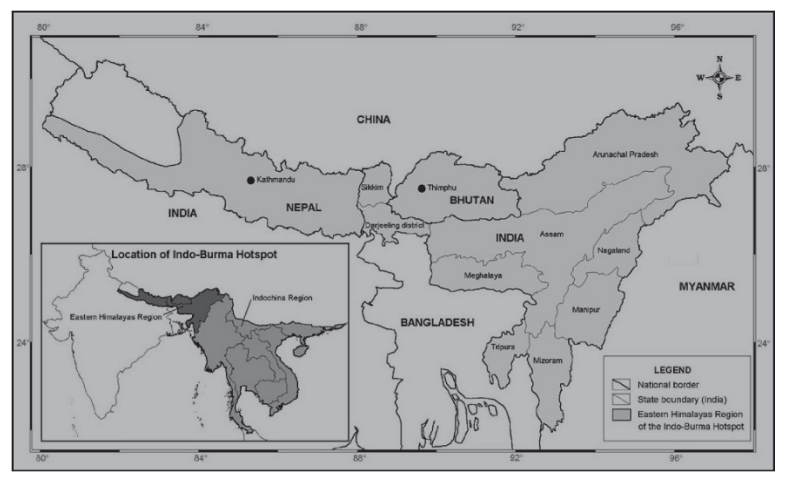

Source: CEPF, 2005

Fig. 1. Eastern Himalayan region covering the area of Nepal, India and Bhutan
Tamor river, the present study area, is one of the main tributaries of Saptakosi which originates from Eastern Himalayan region of Kanchanganga range and ends at Tribeni where it joins with Sunkosi and Arun River. The total length of this river is about $190 \mathrm{~km}$ with $5817 \mathrm{~km}^{2}$ catchment area. The Tamor sub-basin lies in Eastern Himalayan region, which is considered as an earth's biodiversity hotspot. A biodiversity hotspot is a biogeographic region that is both a significant reservoir of biodiversity and is threatened with destruction (Myers et al. 2000). Until recently, the fish diversity of Nepal had been poorly studied or understood, relative to other fauna. However, in the past 10 years (1998 to 2008), because of the increase in ichthyological activity in EHR, seven new species have been reported from Nepal by scientists (WWF 2009).

Shrestha (2001) recorded 182 indigenous fish species from Nepal. Rajbansi (2005) prepared a checklist from the published literature and reported 187 species, while Saund and Shrestha (2007) reported 199 species. Similarly, Shrestha (2008) reported 217 indigenous fish species from Nepal. 
The present study was supported by Critical Ecosystem Partnership Fund (CEPF) according to which the aquatic biodiversity has been neglected in Eastern Himalayan Region of Nepal and hence inventory and research are needed on fishes (CEPF 2005). Therefore, the present study aims to survey on fish diversity, identification of hotspots and conservation management program for local people (Fisher groups) in Tamor river and its tributaries. Although the study focuses on wide range of objectives mentioned above, this article deals only with the fish diversity of the Tamor river.

\section{Study area}

The study area lies in mountainous region of Nepal covering Taplejung, Panchthar and Terhathum districts. Tamor river has shown comparatively higher flow gradient $(0.63 \%)$ at study stations from Mewa confluence at Taplejung district to Hewa confluence at Panchthar district covering $38.25 \mathrm{~km}$ (Fig. 2). The gradient of the river varied considerably that results a series of rapids, runs, riffles and pools along the river coarse and hence differences in river morphology affect fish habitat, distribution pattern and diversity.

Boulders, cobbles, pebbles, gravels and sands are the major characteristic feature of Tamor river which provide appropriate spots for spawning and rearing grounds. The river habitat was found to be very suitable for fishes.

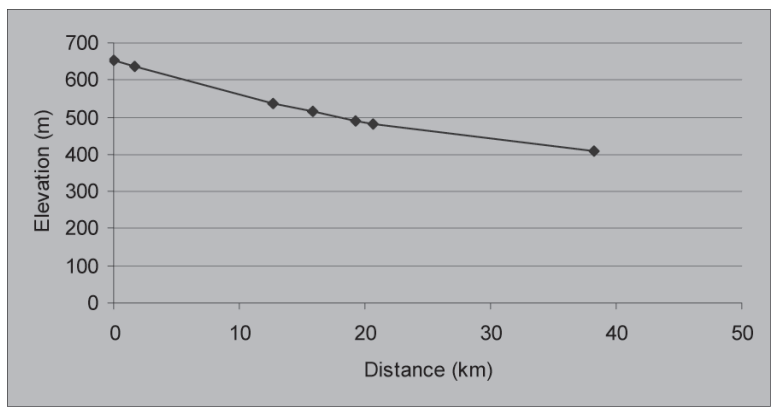

Fig. 2. Flow gradient of Tamor river at different sampling stations (From Station I to VII)

\section{Materials and Methods}

\section{Sampling stations and time schedule of the study}

Seven sampling stations (Mewa confluence-I, Maiwa confluence-II, Khokse confluence-III, Kabeli confluence-IV, Phunguwa confluence-V, Hiunde confluence-VI and Hewa confluence-VII) were selected considering major tributaries of Tamor and their confluence points. Each sampling station consisted of three different sampling sites (A, B and C). All together 21 sampling sites were established to survey the fish diversity and water quality. At each sampling station, site A represents the Tamor river reach (upstream from confluence point), site B represents the tributary of Tamor river and site $\mathrm{C}$ represents river reach at downstream from confluence. Field survey was started on 19 May and ended on 12 July, 2009.

\section{Water quality}

Portable water analysis kit (Hach Chemical CO. Ames., Iowa, USA; Model: Dr. el/2) was used to analyze temperature, $\mathrm{DO}, \mathrm{pH}, \mathrm{CO}_{2}$, alkalinity and total hardness in situ condition in the field.

\section{Fish sampling}

Fishes were sampled in all the sampling stations and their sites. Cast net was mostly used to collect the fish during field visit. However, gill net and other local techniques were also used. Trained local fishermen were hired for this purpose. Fish species available at the local market and caught by local fishermen were also purchased.

Information on local name, economic value and behavior pattern was obtained from fishermen. Fish species collected during the field survey were noted and excess fishes were released to their original habitat.

The collected fish species were preserved in 8$10 \%$ formaldehyde solution for further study. They were identified using standard method of Talwar and Jhingran (1991), K.C. (1999), Shrestha $(1981,1994)$.

\section{Result and Discussion Fish diversity}

An environmental impact assessment (EIA) study for the Tamor Hydropower Project has reported the presence of 19 fish species in Tamor river (Swar \& Shrestha 1998) while EIA study of Kabeli Hydropower Project has reported the presence of 21 fish species (Swar \& Upadhaya 1998).

Thirty fish species have been recorded by this study which are classified systematically. Local fishermen have reported other important fish species like Tor tor, Anguilla bengalensis bengalensis, Bagarius spp., Mastacembelus armatus etc., but none was recorded during the field survey. Myersglanis 
blythi and Psilorhynchoides pseudecheneis are endemic fish species of Nepal among which the later was recorded from all the seven stations and could be considered as a common species of the study area.

\section{Systematic classification}

\section{ORDER: CYPRINIFORMES}

Family: Psilorhynchidae

Genus: Psilorhynchoides Yazdani, Singh and Rao, 1989

Psilorhynchoides pseudecheneis (Menon and Datta) 1961

Family: Cyprinidae

Sub Family: Cyprininae

Labeo dero (Hamilton-Buchanan) 1822

Genus: Naziritor Mirza and Javed 1985

Naziritor chelynoides (McClelland) 1839

Genus: Neolissochilus Rainboth 1985

Neolissiochilus hexagonolepis (McClelland) 1839

Barilius barila (Hamilton-Buchanan) 1822

Barilius barna (Hamilton-Buchanan) 1822

Barilius bendelisis (Hamilton-Buchanan) 1822

Barilius shacra (Hamilton-Buchanan) 1822

Barilius vagra (Hamilton-Buchanan) 1822

Genus: Tor Gray 1834

Tor putitora (Hamilton-Buchanan) 1822

Genus: Garra Hamilton-Buchanan 1822

Garra gotyla gotyla (Gray) 1832

Garra nasuta (McClelland) 1839

Garra annandalei Hora 1921

Genus: Schizothorax Heckel 1838

Schizothorax richardsoni (Gray) 1832

Schizothorax sinuatus (Heckel) 1838

Genus: Schizothoraichthys Misra 1959

Schizothoraichthys curvifrons (Heckel) 1838

Schizothoraichthys labiatus (McClelland) 1842

Schizothoraichthys progastus (McClelland) 1839

Genus: Crossocheilus Kuhl van and Hasselt 1823

Crossocheilus latius latius (Hamilton-Buchanan) 1822

Genus: Botia Gray 1831

Botia almorhae Gray 1831

Botia dario (Hamilton-Buchanan) 1822

Botia histrionica Blyth 1860

Botia lohachata Chaudhauri 1912

Genus: Schistura McClelland 1839

Schistura rupecula inglisi (Hora) 1935

Schistura multifasciatus (Day) 1878
Genus: Nemacheilus

Nemacheilus elongates (Sen and Nalbant) 1981

ORDER: SILURIFORMES

Family: Sisoridae

Genus: Pseudecheneis Blyth 1860

Pseudecheneis crassicauda $\mathrm{Ng}$ and Edds 2005

Genus: Myersglanis Hora and Silas 1952

Myersglanis blythi (Day) 1852

Genus: Glyptothorax Blyth 1861

Glyptothorax indicus Talwar and Jhingran 1991

Glyptothorax telchilta (Hamilton-Buchanan) 1822

Thirty fish species were recorded from different sampling stations which were classified into two orders (Cypriniformes and Siluriformes) and five families (Cyprinidae, Cobitidae, Sisoridae, Balitoridae and Psilorhynchidae). Order Cypriniformes comprises of four families (Cyprinidae, Cobitidae, Balitoridae and Psilorhynchidae) with 26 species while order Siluriformes comprises of one family (Sisoridae) and four species. Cyprinidae, Cobitidae, Balitoridae and Psilorhynchidae comprise $61 \%, 13 \%, 10 \%$ and $3 \%$ respectively, while Sisoridae comprises of $13 \%$ fish species only (Fig. 3).

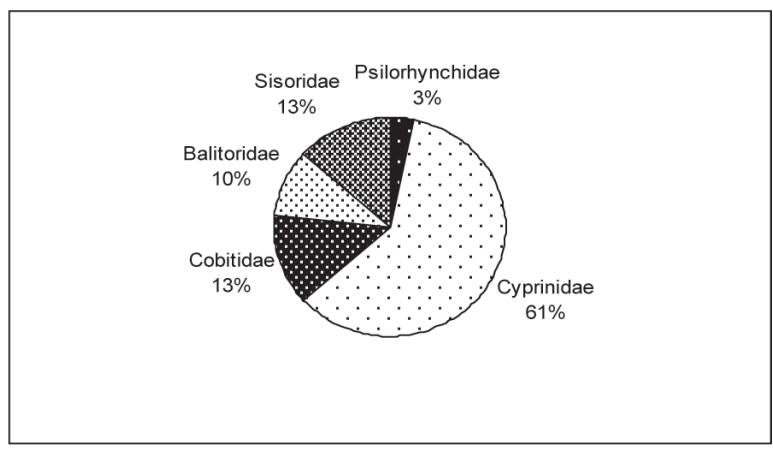

Fig. 3. composition of collected fish

\section{Fish dominancy}

The common species of Tamor river were Psilorhynchoides pseudecheneis (Tite) followed by Barilius shacra (Faketa), Barilius bendelisis (Faketa), Barilius barila (Faketa), Schizothoraichthys labiatus (Chuche Asala), S. progastus (Chuche Asala), Schizothorax richardsonii (Buche Asala), Neolissochilus hexagonolepis (Katle) and Garra annandalei (Buduna) (Table 1). 
Table 1. Dominant fish species recorded at different sampling stations

\begin{tabular}{|c|c|c|c|c|}
\hline S.N. & Station No. & Name of station & Scientific name of the dominant/key species & $\begin{array}{l}\text { Local name of the } \\
\text { species }\end{array}$ \\
\hline 1 & I & Mewa confluence & Barilius shacra, Psilorhynchoides pseudecheneis & Faketa, Tite \\
\hline 2 & II & Maiwa confluence & $\begin{array}{l}\text { Psilorhynchoides pseudecheneis, Schizothoraichthys } \\
\text { labiatus, S. progastus, Schizothorax richardsonii }\end{array}$ & $\begin{array}{l}\text { Tite, Chuche Asala, } \\
\text { Buche Asala }\end{array}$ \\
\hline 3 & III & Khokse confluence & $\begin{array}{l}\text { Schizothoraichthys labiatus, Schizothorax richardsonit } \\
\text { Barilius barila. }\end{array}$ & $\begin{array}{l}\text { Chuche Asala, Buche } \\
\text { Asala Faketa }\end{array}$ \\
\hline 4 & IV & Kabeli confluence & Neolissochilus hexagonolepis, Barilius bendelisis & Katle, Faketa \\
\hline 5 & $\mathrm{~V}$ & Phunguwa confluence & $\begin{array}{l}\text { Barilius barila, Schizothoraichthys progastus, } \\
\text { Crossocheilus latius latius }\end{array}$ & $\begin{array}{l}\text { Faketa, Chuche Asala, } \\
\text { Lohari }\end{array}$ \\
\hline 6 & VI & Hiunde confluence & $\begin{array}{l}\text { Neolissochilus hexagonolepis, Schizothorax sinuatus } \\
\text { Barilius bendelisis }\end{array}$ & $\begin{array}{l}\text { Katle, Buche Asala, } \\
\text { Faketa }\end{array}$ \\
\hline 7 & VII & Hewa confluence & Barilius bendelisis, Garra annandalei & Faketa, Budhuna \\
\hline
\end{tabular}

\section{Economic importance of fish species}

Most of the species collected during the field survey have economic value as food, medicinal, recreational and aesthetic purposes. Fishes like Asala, Sahar, Katle and Thend have good food value while some of the fishes such as Tite, Kabre and Thend have medicinal values.

Table 2. Water quality of the study area

\section{Water quality}

The water quality parameters i.e. air temperature (22$\left.26.3^{\circ} \mathrm{C}\right)$, water temperature $\left(16.0-19.0^{\circ} \mathrm{C}\right), \mathrm{DO}(9.7-10$ $\mathrm{ppm}), \mathrm{pH}(7.3-7.5)$, alkalinity $(17.1 \mathrm{mg} / \mathrm{l})$, total hardness (28.5-34.2 mg/l), $\mathrm{CO}_{2}(5 \mathrm{mg} / \mathrm{l})$ and conductivity (37.7$56.7 \mu \mathrm{s} / \mathrm{cm}$ ) were found within the suitable range for cold water fishes (Table 2).

\begin{tabular}{l|l|l|l|l|l|l|l|l}
\hline \multirow{2}{*}{\multicolumn{1}{c|}{ Parameters }} & \multirow{2}{*}{ Unit } & \multicolumn{7}{c|}{} \\
\cline { 3 - 8 } & & I & II & III & IV & V & VI & \multicolumn{1}{c}{ VII } \\
\hline Air temperature & ${ }^{\circ} \mathrm{C}$ & 22.3 & 23.3 & 22.3 & 22.0 & 25.3 & 24.0 & 26.3 \\
Water temperature & ${ }^{\circ} \mathrm{C}$ & 17.3 & 16.0 & 17.3 & 18.7 & 18.3 & 17.3 & 19.0 \\
$\mathrm{DO}$ & $\mathrm{ppm}$ & 9.7 & 9.7 & 9.7 & 9.7 & 10.0 & 9.7 & 9.7 \\
$\mathrm{pH}$ & & 7.4 & 7.5 & 7.4 & 7.3 & 7.3 & 7.3 & 7.4 \\
Alkalinity & $\mathrm{mg} / 1$ & 17.1 & 17.1 & 17.1 & 17.1 & 17.1 & 17.1 & 17.1 \\
Total hardness & $\mathrm{mg} / 1$ & 34.2 & 28.5 & 34.2 & 34.2 & 34.2 & 34.2 & 28.5 \\
$\mathrm{CO}_{2}$ & $\mathrm{mg} / 1$ & 5.0 & 5.0 & 5.0 & 5.0 & 5.0 & 5.0 & 5.0 \\
Conductivity & $\mu \mathrm{s} / \mathrm{cm}$ & 56.7 & 48.0 & 56.7 & 37.7 & 43.7 & 41.3 & 49.0 \\
\hline
\end{tabular}

Based on present study, evaluating the morphological characters of river with plenty of spawning and rearing grounds, rich water quality and fish diversity, the whole study area was observed to be intact and undisturbed. However, many of the proposed hydropower projects in Saptakoshi, Tamor, Kabeli, Phawa, Maiwa etc. (NEA 2007/08) will lead this intact environment into critically fish hotspots in future. More survey works at different seasons are needed to cover the complete information regarding the fish species and their aquatic habitat.

\section{Acknowledgement}

Authors are very thankful to Critical Ecosystem Partnership Fund (CEPF), WWF-Nepal for providing research fund. Similarly, we are also grateful to Mr. Raj Kapur Napit, Mr. Bisnu Bahadur Silwal and Mr. Mukund Thapa for their painstaking help during field survey and lab work. 


\section{References}

CEPF. 2005. Ecosystem Profile. Eastern Himalayan region, Final version, Feb. 2005.

K.C., Jayaram 1999. The freshwater fishes of the Indian region. Narendra Publishing House, Delhi, India. $551 \mathrm{pp}$.

Myers, N., R.A. Mittermeier, C.G. Mittermeier, G.A. B. da Fonseca and J. Kent. 2000. Biodiversity hotspots for conservation priorities. Nature 403:853-858.

NEA. 2007/08. A year in review. Nepal Electricity authority. Fiscal Year 2007/08.

Rajbanshi, K.G. 2005. Review on current taxonomic status and diversity of fishes in Nepal. Royal Nepal Academy of Science and Technology. Occasional paper. No. 10. $41 \mathrm{pp}$.

Saund T.B. and J. Shrestha. 2007. Fish and benthic fauna in Kulekhani reservoir. Nepal Journal of Science and Technology 8: 63-68.

Shrestha, J. 1981. Fishes of Nepal. Curriculum Development Centre, Tribhuvan University, Kathmandu, Nepal. 318 pp.

Shrestha, J. 1994. Fishes, fishing implements and method of Nepal. Published by Smt. M.D. Gupta, Lalitpur Colony, Lashkar (Gwalior), India.
Swar, D.B. \& J. Shrestha 1998. Fishery baseline and impact assessment of Dudhkoshi-I hydropower project area. Mediun hydropower study project, NEA.

Swar D.B. \& K.K. Upadhaya K.K. 1998. Fisheries baseline and impact assessment of Kabeli " $A$ " hydropower project area. A report submitted to NEA.

Shrestha, J. 2001. Taxonomic revision of fishes of Nepal. In: Biodiversity, agriculture and pollution in South Asia. (Eds. P.K. Jha et.al.). ECOS, Kathmandu. pp. 171-180.

Shrestha, J. 2003. Taxonomic revision of fishes of Nepal. In: Cold water fisheries in the trans-Himalayan countries. FAO Fisheries technical paper No. 431. pp. 273-288.

Shrestha T.K. 2008. Ichthyology of Nepal. A study of fishes of the Himalayan waters. Himalayan Ecosphere. Kathmandu, Nepal. pp. 1-388.

Talwar, P.K. and A.G. Jhingran. 1991. Inland fishes of india and adjacent countries. Vol. I \& II Oxford and IBH publishing Co. PVT. LTD., New Delhi, India.

WWF 2009. The Eastern Himalayas where the worlds collide. New species discoveries. Living Himalayas Network Initiatives. pp. 1-28. 
Nepal Journal of Science and Technology 10 (2009) 